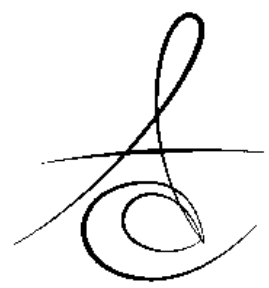

\title{
EVALUATION OF THE RELATIONSHIP BETWEEN THE PERCEPTION OF ORTHODONTIC MALOCCLUSION AND SELF-ESTEEM OF PATIENTS SEEKING ORTHODONTIC TREATMENT
} ORTODONTİK TEDAVİ OLMAK İSTEYEN HASTALARIN ORTODONTİK BOZUKLUK
ALGISI İLE BENLİK SAYGISI ARASINDAKİ İLİŞKİNİN DEĞERLENDİRİLMESİ

\author{
Dr. Zeynep ÇOBAN BÜYÜKBAYRAKTAR*
}

Prof Dr. Cenk DORUK*

\author{
Makale Kodu/Article code: 4413 \\ Makale Gönderilme tarihi: 04.06.2020 \\ Kabul Tarihi: 13.01.2021
}

DOI : $10.17567 /$ ataunidfd. 860100

Zeynep Çoban Büyükbayraktar : ORCID ID: 0000-0002-4511-5480

Cenk Doruk : ORCID ID: 0000-0002-4399-2770

\section{ABSTRACT}

Aim: This study aims to determine whether there is a relationship between the perception of orthodontic malocclusion and selfesteem in patients admitted to our clinic in order to receive orthodontic treatment. At the same time, the perception of orthodontic malocclusion was compared in terms of patient and orthodontist in the study.

Materials and Methods: A total of 152 individuals (74 males and 78 females) aged between 14-18 years were included in the study. In our study, we used the Index of Orthodontic Treatment Need (IOTN) aesthetics scale for the perception of orthodontic malocclusions, the Rosenberg Self-Esteem Scale for the evaluation of self-esteem, and the Facial Image Scale (FIS) for the determination of the current mood. The chi-square test was used to evaluate the relationship between gender and results, Spearman's correlation test was used to evaluate the relationship between scores given by the patients and orthodontist to the IOTN aesthetics scale, self-esteem level and FIS, and the two-way repeated measures ANOVA test was used to examine these parameters with the gender variable.

Results: There was no significant relationship between the patients' perception of orthodontic malocclusion and self-esteem $(p>0.05)$. The relationship between the scores given by the patients and orthodontist to the IOTN aesthetics scale was significant $(p<0.05)$. There was no significant relationship between the gender variable and other parameters $(p>0.05)$.

Conclusion: Our results show that there is no relationship between the patients' perception of orthodontic malocclusion and self-esteem.

Keywords: Psychology; Malocclusion; Adolescent

öz

Amaç: Bu çalışmanın amacı ortodontik tedavi olma isteği ile kliniğimize başvuran hastaların ortodontik bozukluk algısı ile benlik saygısı arasında bir ilişki olup olmadığını belirlemektir. Çalışmada aynı zamanda ortodontik bozukluk algısının hasta ve hekim açısından karşılaştırması da yapıımışıı.

Bireyler ve Yöntem: Çalışma yaşları 14-18 arasında olan, 74 erkek ve 78 kız toplam 152 birey üzerinde yürütülmüştür. Çalışmamızda ortodontik bozuklukların algılanmasında Ortodontik Tedavi Gereksinimi İndeksi (OTGI) estetik skalası, benlik saygısının değerlendirilmesinde Rosenberg Benlik Saygısı Ölçeği ve o anki duygu durumunun tespiti için Yüz Görüntü Ölçeği (YGÖ) kullanılmışıı. Sonuçların cinsiyet ile ilişkisinin değerlendirilmesinde ki kare testi, hastaların ve hekimin OTGI estetik skalasına verdikleri puanlarla, benlik saygısı düzeyi ve YGÖ arasındaki ilişki Spearman korelasyon testi, bu parametreleri cinsiyet değişkeniyle beraber incelemek için 2×2 tekrarlı ölçümler Anova testi kullanılmıştır.

Bulgular: Hastaların ortodontik bozukluk algısı ile benlik saygısı arasında anlamlı ilişki bulunmamışıı ( $>>0,05)$. Hastaların ve hekimin OTGI estetik skalasına verdikleri puanlar arasındaki ilişki anlamlıdır $(p<0,05)$. Cinsiyet değişkeniyle diğer parametreler arasında anlamlı ilişki bulunmamıştır $(p>0,05)$.

Sonuç: Bulgularımız hastaların ortodontik bozukluk algısı ile benlik saygısı arasında bir ilişki olmadığını göstermektedir Anahtar Kelimeler: Psikoloji; Maloklüzyon; Adölesan

${ }^{*}$ Sivas Cumhuriyet Üniversitesi Diş Hekimliği Fakültesi Ortodonti AD.

Kaynakça Bilgisi: Çoban Büyükbayraktar Z, Doruk C. Evaluation of the relationship between the perception of orthodontic malocclusion and selfesteem of patients seeking orthodontic treatment. Atatürk Üniv Diş Hek Fak Derg 2021; 31: 182-7.

Citation Information: Coban Buyukbayraktar Z, Doruk C. Evaluation of the relationship between the perception of orthodontic malocclusion and selfesteem of patients seeking orthodontic treatment. J Dent Fac Atatürk Uni 2021; 31: 182-7. 


\section{INTRODUCTION}

The facial appearance and teeth have a significant influence on the individual's adaptation to life. ${ }^{1}$ The main reasons for receiving orthodontic treatment are psychosocial problems due to facial and dental appearance. ${ }^{2}$

It is said that there is a relationship between the facial attractiveness of children and adolescents and their grade point averages (GPAs), friendship and social relationships. ${ }^{3}$ However, the ratios of individuals affected by malocclusions are variable, and there is no evidence that people with visible disorders will generally be affected emotionally. ${ }^{4}$

Malocclusion is defined as the disorder that occurs with the loss of the normal occlusal relationship between the teeth when the upper and lower jaw are closed. ${ }^{5}$ In order to understand the effect of malocclusion on psychology, some factors should be examined. ${ }^{6}$ One of these factors is self-esteem. Selfesteem reflects one's assessment of one's own worth. ${ }^{7}$ Physical appearance plays an important role in selfesteem in every period of life ${ }^{8,9}$ Rivera et al. ${ }^{10}$ reported that the body perceptions of children and adolescents with malocclusion are similar to the general population and that they show positive self-esteem. In patients with low self-perception or low self-esteem, the person's self-assessment of the severity of the existing malocclusion rather than clinical assessment is said to be more effective in the development of this condition. ${ }^{10}$ It has been found that the presence of malocclusion affects the emotional and social wellbeing of the individual. ${ }^{11}$ In other study, the presence of malocclusion was not clinically related to selfperception and self-esteem. ${ }^{12}$ In this way, it can be said that malocclusion can affect not only oral health but also the social and emotional development of a person; however, as can be seen, the data in the relevant literature are controversial.

The perception of the need for orthodontic treatment and the perception of malocclusion differ between the orthodontist and the patient. In the perception of orthodontic disorders, orthodontists think more about function and occlusion, while patients consider the aesthetic, social, and financial aspects of treatment. ${ }^{13}$ Patients and their families believe that their popularity will increase with the aesthetic improvement of the jaw and facial system at the end of orthodontic treatment, and thus, their selfconfidence may increase in their social environment.
The aim of this study is to state whether there is a relationship between the perception of orthodontic malocclusion and self-esteem in patients admitted to our clinic in order to receive orthodontic treatment and to compare the perception of orthodontic malocclusion in terms of patients and orthodontists.

\section{Materials and Methods}

A total of 152 individuals (74 males and 78 females) aged between 14-18 years, admitted to the Orthodontic Clinic of Sivas Cumhuriyet University Faculty of Dentistry (between January 2019 and May 2019) for treatment, were included in the study using convenience sampling method. Generally healthy patients who haven't had orthodontic treatment before and had not been diagnosed with any mental or physical disease, were included in the study. Patients who have had orthodontic treatment before or who were receiving orthodontic treatment at the time of the study and who were diagnosed with any mental or physical disease or craniofacial anomaly, were excluded from the study.

In this study, when $a=0.05 \beta=0.05(1-\beta)=$ 0.95 , it was decided that the total sample number should consist of at least 120 people and the power of the test was found to be P: 0.95. However, all of the patients who applied at a certain time and complied with the conditions of inclusion were included in the study.

The ethics committee approval was obtained for the study with the verbal and written consent of the patients who applied to our clinic and their parents separately (Ethics committee decision no: 2018-12/14, Date: 05.12.2018).

Index of Orthodontic Treatment Need (IOTN): The IOTN, defined by Brook and Shaw is used as an objective method to determine the need for treatment. ${ }^{14}$ It classifies patients according to the degree of malocclusions and how they are perceived aesthetically to better determine patients who should benefit most from orthodontic treatment. It consists of two parts: the dental health scale and the aesthetic scale. On the aesthetic scale, the dental image of the patient is matched with the most similar photograph (Figure 1). The photos on the aesthetic scale are graded from 1 to 10 , and the higher the score, the worse the aesthetic condition. On the dental health scale, the degree of the existing malocclusion is determined. Thus, the patient's need for orthodontic treatment is determined. 

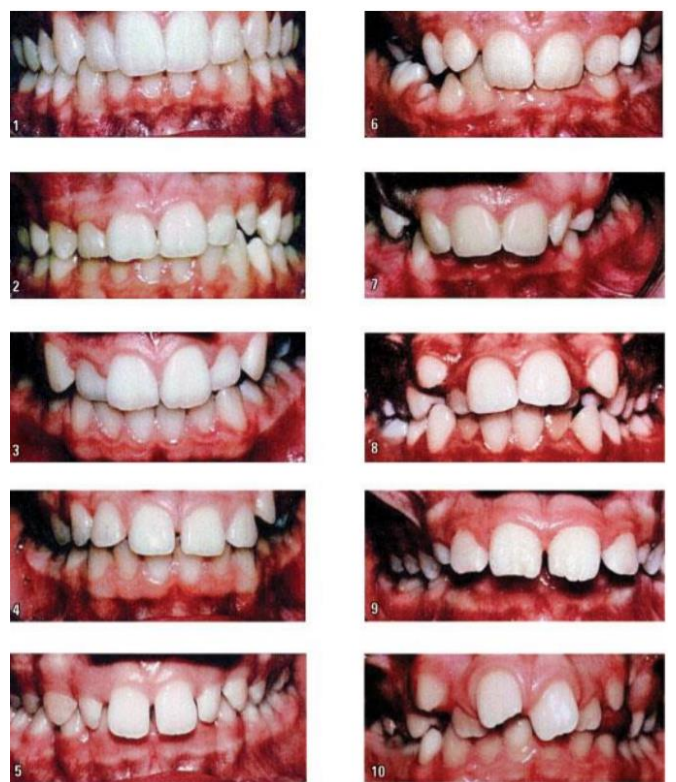

Figure 1. Index of Orthodontic Treatment Need (IOTN)

Rosenberg Self-Esteem Scale: It was developed by Morris Rosenberg in 1965 as a selfesteem measurement tool for adolescents. ${ }^{15} \mathrm{Dr}$. Füsun Çetin Çuhadaroğlu translated the scale into Turkish in 1985 and made it available for use in adolescents in Turkey by doing back translation and performing validity and reliability studies in high school students. ${ }^{16}$ In his study on adolescents in the United States of America, Rosenberg used other small subscales to evaluate self-esteem with various other characteristics. These were also included in the validity and reliability study. However, the measured characteristics and evaluations of each subscale are different. The scale consisted of a total of 63 items and 12 sub-scales, which were structured from multiple choice questions. In our study, the first 10 items related to the self-esteem part of the 63-item were used. Questions are scored using the Guttman evaluation method. 0-1 points were accepted to be a high self-esteem level, 2-4 points were accepted to be a moderate self-esteem level, and 5-6 points were accepted to be a low self-esteem level. In other words, the high total score obtained from the scale showed that the self-esteem level was low.

Facial Image Scale (FIS): There are five different types of faces between happy and unhappy (Figure 2). Children were asked to show the facial shapes they feel most at the time. The most positive facial shape in the scale is given 1 point, while the most negative facial shape is given 5 points. An increase in score indicates that the child was unhappy.

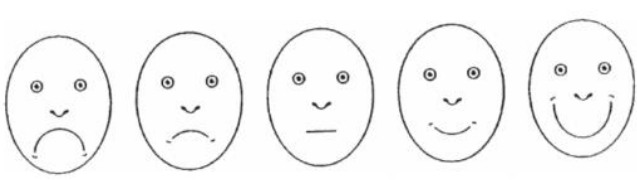

Figure 2. Facial Image Scale (FIS)

The IOTN aesthetic scale was used in our study. The patient was asked to select the most similar photograph to him/her from the 10 photographs on the aesthetic scale. The orthodontist, who was also calibrated and trained by a professor, selected the most matched photograph for that patient. The patient answered only the first 10 -item self-esteem part of the Rosenberg self-esteem test. The IOTN aesthetic scale was used to measure the differences of patients and physicians perception of orthodontic malocclusions, and the Rosenberg self-esteem scale was used to evaluate patients' self-esteem. ${ }^{12,17}$ On the Facial Image Scale, the patient was asked to select the face shape he/she felt at that moment.

\section{Statistical Analysis}

Data collected from our study were uploaded to the SPSS program (Ver: 15.0, IBM Corp. New York, USA). Average, standard deviation and frequency distributions were studied in data evaluation. The chisquare test was applied in the evaluation of the relationship between results and data of gender, and differences of $p<0.001$ were accepted as statistically significant. The nonparametric Spearman's rho correlation coefficient was calculated since sequential data were used when examining the relationship between self-esteem level and FIS, and the scores given by the patients and orthodontist to the IOTN aesthetic scale. Since the IOTN aesthetic scale scores of the patient and orthodontist were examined together with the gender variable and both intergroup and intragroup comparisons were wanted to be performed at the same time, the two-way repeated measures ANOVA test was used.

\section{RESULTS}

Our study consisted of a total of 152 people (74 males $(48.7 \%)$ and 78 females $(51.3 \%)$ ). The mean age of the individuals included in the study was 15.13 years.

The relationship between the scores given by the patients and the orthodontist to the IOTN aesthetic scale was significant $(r=0.523 p<0.001)$. There was no significant difference between the scores given by the patients and the orthodontist to

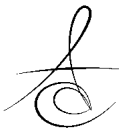


the IOTN aesthetic scale (Table 1 ) according to the gender variable $(F(1.50)=2.024: p=0.157)$. Before the two-way repeated measures ANOVA test, the covariance equation from the assumptions of this test was examined by the Box test, and the variance equation was examined by Levene's test. In all of these tests, it was determined that these assumptions were met because values greater than 0.001 were obtained.

Table 1. Distribution of the scores given to the IOTN aesthetic scale by patients and orthodontist according to the gender variable

\begin{tabular}{|c|c|c|c|c|}
\hline Gender & $\begin{array}{l}\text { Patient } \\
\text { male }\end{array}$ & female & male & $\begin{array}{c}\text { IOTN Orthodonti } \\
\text { female }\end{array}$ \\
\hline $\mathrm{N}$ & 74 & 78 & 74 & 78 \\
\hline $\begin{array}{l}\text { Mean } \pm \text { Std. } \\
\text { Deviation }\end{array}$ & $3,8514 \pm 2,44$ & $4,0513 \pm 2,27$ & $4,0946 \pm 2,00$ & $3,7949 \pm 1$ \\
\hline Total & \multicolumn{3}{|c|}{$3,9539 \pm 2,35$} & $3,9408 \pm 1,97$ \\
\hline
\end{tabular}

*IOTN: : Index of Orthodontic Treatment Need

There was no significant relationship between gender and FIS $\left(X^{2}(4, n=152)=4.85 ; p=0.303\right)$. There was no significant relationship between gender and self-esteem $\left(x^{2}(2, n=152)=0.337 ; p=0.845\right)$.

While there was a significant relationship between the scores given by the patients to the IOTN aesthetic scale and FIS $(p<0.001)$, there was no significant relationship with self-esteem $(p>0.001)$. A significant relationship was found between the scores given by the orthodontist to the IOTN aesthetic scale $(p<0.001)$, but no significant relationship was found between the scores and self-esteem ( $p>0.001)$ (Table 2).

Table 2. The comparison of the IOTN scores of the patients and orthodontist according to the FIS and self-esteem categories

\begin{tabular}{lllll} 
& IOTN Patient & \multicolumn{2}{l}{ IOTN Orthodontist } & \\
& $\mathrm{r}$ & $\mathrm{p}$ & $\mathrm{r}$ & $\mathrm{p}$ \\
Facial Image Scale & $.303^{* *}$ & $.000^{*}$ & $.303^{* *}$ & $.000^{*}$ \\
Self-esteem & & & & \\
\hline
\end{tabular}

-IOTN: Index of Orthodontic Treatment Need FIS: Facial Image Scale ${ }^{*} \chi 2$ significance level. $p<0.001 \quad{ }^{* *} r$ correlation coefficient

\section{DISCUSSION}

Both research and subjective experience show that malocclusion and dental aesthetic perceptions and evaluations of patients and orthodontists are different. ${ }^{18,19}$ Although most patients seem to be aware of their malocclusion characteristics, they cannot perceive the severity of the disorder as much as the orthodontist or dentist. ${ }^{20}$ When we look at the expectations from orthodontic treatment, we see that aesthetic reasons come first. ${ }^{21}$ In the evaluation made by orthodontists, the oral health and function of the patient take precedence over aesthetics, and accordingly, concessions can be made in terms of aesthetics. ${ }^{12}$ Therefore, in our study, patients were asked to choose the most suitable photograph from the IOTN aesthetic scale. At the same time, the orthodontist also selected the most suitable photograph for that patient, and the relationship between the two was evaluated. In our study, a significant relationship was found between the scores given by the patients and orthodontist to the IOTN aesthetic scale. In other words, the aesthetic perceptions of patients and orthodontists are observed to be very close to each other. This finding is incompatible with the findings obtained by Önçağ et al. ${ }^{12}$, who stated that the level of patients' perception of orthodontic malocclusions was insufficient. Studies show that $40 \%$ of patients are disturbed by the presence of malocclusion, and $93 \%$ resort to treatment due to aesthetic problems. ${ }^{22,24}$ Patients who are aware of aesthetic problems are willing to be treated and this provides positive effects on patient motivation.

In a study evaluating the relationship of selfconcept, loneliness, and social phobia scores with gender, it was stated that gender did not have a significant relationship with the mentioned concepts. Furthermore, Jung et al. ${ }^{25}$ stated that malocclusion caused more anxiety in women, or the perception of the facial and dental image had different psychosocial effects between genders. In our study, when Table 1 is examined, it is observed that the females' scores are higher in terms of the scores given by the patients to themselves, and the males' scores are higher in terms of the scores given by the orthodontist. In this respect, we can conclude that females perceive their orthodontic malocclusions more negatively. However, in our study, no significant rela- tionship was found between gender and the scores gi- ven by the patient and orthodontist to the IOTN aest- hetic scale, FIS, and self-esteem. When we examine our orthodontic patient population, we see that girls want this treatment more than boys. The findings we obtained from our study explain the reason for this si- tuation. Female patients who perceive their ortho- dontic disorders worse are in line for this treatment.

Rosenberg ${ }^{15}$ defined self-esteem as a positive or negative attitude of an individual toward 
himself/herself. Kulaksızoğlu ${ }^{26}$ also defined selfesteem as the degree of liking and the emotional side of the individual's self.

Kılıç 27 found a significant relationship between social appearance anxiety and self-esteem. Venete et al. ${ }^{28}$ found a significant relationship between dental perception and self-esteem. In another study, Phillips et al. ${ }^{29}$ reported that self-perception of the individual's dentofacial appearance was more related to selfconcept than to malocclusion. Perillo et al. ${ }^{30}$ also found a significant relationship between the presence of malocclusion and self-concept. These findings are not compatible with our findings.

In addition, Önçağ et al. ${ }^{12}$ found no significant relationship between the perception of malocclusion and self-esteem in their study. Çokakoğlu et al. ${ }^{31}$ also found that different malocclusions do not affect a person's self-concept. In our study, no significant relationship was found between the perception of orthodontic malocclusion and self-esteem, because with the aesthetic component of the IOTN, only the dental appearance of individuals can be evaluated. Adolescents, however, may also be obsessed with another area of facial appearance, which may affect their self-esteem. In the study by Phillips et al. ${ }^{29}$, a robust relationship was found between the FIS and self-concept. In our study, a significant relationship was found between the perception of orthodontic malocclusion and FIS. The need for orthodontic treatment is increasing with the presence of patients who become aware of orthodontic disorders and want to correct this condition. Therefore, physicians should make a treatment plan in line with the needs and complaints of the patients and take into account the psychology of the patients.

\section{LIMITATIONS}

Since the IOTN aesthetic scale does not contain some malocclusion types in the detection of orthodontic disorder perception, it may not be an adequate scale. The scale of the self-esteem and the FIS are subjective assessment tools and the clinical significance of our results is controversial. The findings of the study cannot be generalized to the whole society, as it covers only patients who apply to the university clinic at a certain time.

\section{CONCLUSION}

In our study, it was found that patients and orthodontists showed similar results in terms of the perception of orthodontic malocclusions. Another remarkable result is that females perceive their orthodontic malocclusions more negatively than they actually are. No significant relationship was found between the perception of malocclusion and selfesteem.

\section{Acknowledgement}

We would like to thank Idea Tercüme (www.ideatercume.com) for English language translation.

\section{REFERENCES}

1. Proffit W, Fields $\mathrm{H}$ and Sarver D. Contemporary Orthodontics. St Louis: MO: Mosby Elsevier; 2012.

2. Samsonyanová $L$ and Broukal Z. A systematic review of individual motivational factors in orthodontic treatment: facial attractiveness as the main motivational factor in orthodontic treatment. Int Dent J 2014; 2014: 937278.

3. Rosen LH and Underwood MK. Facial attractiveness as a moderator of the association between social and physical aggression and popularity in adolescents. J Sch Psychol 2010;48:313-33.

4. Heravi F, Farzanegan F, Tabatabaee $M$ and Sadeghi $M$. Do malocclusions affect the oral health-related quality of life? Oral Health Prev Dent 2011;9:229-33.

5. Kazancı DF, Ceylan İ. Ortodontik indeksler. Atatürk Üniv Diş Hek Fak Derg 2010;20:62-75.

6. Shaw WC, Richmond S, Kenealy PM, Kingdon A and Worthington H. A 20-year cohort study of health gain from orthodontic treatment: psychological outcome. Am J Orthod Dentofacial Orthop 2007;132:146-57.

7. Akfirat ON. Investigation of relationship between psychological well-being, self esteem, perceived general self-efficacy, level of hope and cognitive emotion regulation strategies. J Stud Int Educ 2020;7:286-306.

8. Sousa ND, Tsingene F. Saef-Smile's Aesthetic Evaluation form: a useful tool to improve communications between clinicians and patients during multidisciplinary treatment. Eur J Esthet Dent 2011;6:160-76.

9. Koronczai B, Kökönyei G, Urbán R, Kun B, Pápay O, Nagygyörgy K, Griffiths MD, Demetrovics Z. The mediating effect of self-esteem, depression and anxiety between satisfaction with body appearance and problematic internet use. Am J Drug Alcohol Abuse 2013;39:259-65.

10. Rivera SM, Hatch JP, Rugh JD, editors. Psychosocial factors associated with orthodontic 
BÜYÜKBAYRAKTAR, DORUK

and orthognathic surgical treatment. Semin Orthod 2000;6:259-69.

11. Bittencourt JM, Martins $L P$, Bendo $C B$, Vale MP, Paiva SM. Negative effect of malocclusion on the emotional and social well-being of Brazilian adolescents: a population-based study. Eur J Orthod 2017;39:628-33.

12. Önçağ G, Doğan S, Aras I, Topçu O, Işıksal E. Türk Toplumunda ortodontist, dişhekimliği öğrencisi ve diğer toplum bireyleri arasındaki ortodontik düzensizliklerin algılanma farklılıkları. EÜ Diş Hek Fak Derg 2009;30:105-14.

13. Hamdan AM. The relationship between patient, parent and clinician perceived need and normative orthodontic treatment need. Eur J Orthod 2004; 26:265-71.

14. Tolessa $M$, Singel AT, Merga $H$. Epidemiology of orthodontic treatment need in southwestern Ethiopian children: a cross sectional study using the index of orthodontic treatment need. BMC Oral Health 2020;20:1-6.

15. Rosenberg M. Society and the adolescent selfimage: Princeton university press; United States of America 2015.p.3-16.

16. Çuhadaroğlu F. Adolesanlarda benlik saygısı. Uzmanlık Tezi, Hacettepe Üniv Tıp Fak Psikiyatri Anabilim Dalı, Ankara 1986.

17. Clijmans M, Lemiere J, Fieuws S, Willems G. Impact of self-esteem and personality traits on the association between orthodontic treatment need and oral health-related quality of life in adults seeking orthodontic treatment. Eur J Orthod 2015;37:643-50.

18. Klages U, Claus N, Wehrbein $H$, Zentner A. Development of a questionnaire for assessment of the psychosocial impact of dental aesthetics in young adults. Eur J Orthod 2005;28:103-11.

19. Klages U, Bruckner A and Zentner A. Dental aesthetics, self-awareness, and oral health-related quality of life in young adults. Eur J Orthod 2004; 26:507-14.

20. Mandall N, Wright J, Conboy F, O'Brien K. The relationship between normative orthodontic treatment need and measures of consumer perception. Community Dent Health 2001;18:3-6.

21. AlQuraini N, Shah R, Cunningham SJ. Perceptions of outcomes of orthodontic treatment in adolescent patients: a qualitative study. Eur J Orthod 2019;41:294-300.

22. Chen M, Wang D-W, Wu L-P. Fixed orthodontic appliance therapy and its impact on oral health- related quality of life in Chinese patients. Angle Orthod 2010;80:49-53.

23. Omer YT, Bouserhal J, Hawas N and El Sayed AAM. Association between normative and selfperceived orthodontic treatment need in a Lebanese population. Int Orthod 2016;14:386-98.

24. Watts GD, Christou P, Antonarakis GS. Experiences of individuals concerning combined orthodontic and orthognathic surgical treatment: a qualitative Twitter analysis. Medical Principl Prac 2018; 27: 227-35.

25. Jung $\mathrm{MH}$. Evaluation of the effects of malocclusion and orthodontic treatment on self-esteem in an adolescent population. Am J Orthod Dentofac Orthop 2010;138:160-166.

26. Kulaksızoğlu A. Ergenlik psikolojisi. İstanbul, Remzi: 2011.p.41-9.

27. Kılıç M. Üniversite öğrencilerinin sosyal görünüş kaygıları ile benlik saygıları ve yalnızlık düzeyleri arasındaki ilişkinin incelenmesi: Selçuk Üniversitesi Sağlık Bilimleri Enstitüsü; 2015.

28. Venete A, Trillo-Lumbreras E, Prado-Gascó V-J, Bellot-Arcís C, Almerich-Silla J-M, Montiel-Company J-M. Relationship between the psychosocial impact of dental aesthetics and perfectionism and selfesteem. J Clin Exp Dent 2017;9:1453.

29. Phillips C, Beal KNE. Self-concept and the perception of facial appearance in children and adolescents seeking orthodontic treatment. Angle Orthod 2009;79:12-16.

30. Perillo L, Esposito M, Caprioglio A, Attanasio S, Santini AC, Carotenuto M. Orthodontic treatment need for adolescents in the Campania region: the malocclusion impact on self-concept. Patient Prefer Adherence 2014;8:353.

31. Çokakoğlu S, Nalçacı R, Aktepe E, Özyer G. Do different orthodontic malocclusions affect patients' self-concept and psychosocial status? Turk J Orthod 2016; 29:27.

\section{Sorumlu Yazarın Yazışma Adresi} Dr. Zeynep ÇOBAN BÜYÜKBAYRAKTAR Sivas Cumhuriyet Üniversitesi Diş Hekimliği Fakültesi Ortodonti e-mail:dtzeynepcoban@gmail.com 